Annals of Plant and Soil Research 23(3): 314-318 (2021)

https://doi.org/10.47815/apsr.2021.10076

\title{
Yield and quality performance of bottle gourd [Lagenaria siceraria (Mol.) Standl.] genotypes in humid tropical lowland of Kerala
}

\author{
M. YOGANANDA, M. RAFEEKHER, S. SARADA AND O.N. SHRUTHY
}

Department of Vegetable Science, College of Agriculture, Kerala Agricultural University, Vellayani, Kerala Received: March, 2021: Revised accepted: June, 2021

\begin{abstract}
The present investigation was carried out at the Department of Vegetable Science, College of Agriculture, Kerala Agricultural University, Vellayani, during 2019-2020 to study the performance of bottle gourd genotypes. Among the genotypes, the BG-3 recorded the lower most node to fruit production (13.7) and highest fruit set per cent (43.4\%). BG-2 was earliest to first fruit harvest (57.8 days). IC 371745 recorded longer fruit length $(68.8 \mathrm{~cm})$ which was at par with IC $538142(62.2 \mathrm{~cm})$. Genotype IC417704 recorded maximum fruit diameter and flesh thickness $(15.97 \mathrm{~cm}$ and $12.56 \mathrm{~cm}$ ). Genotype IC 331101 recorded the lowest rind thickness $(1.69 \mathrm{~mm})$ and IC 536593 recorded the highest fruit weight $(2.41 \mathrm{~kg})$. Tvpm Local recorded highest number of fruits per vine (6) followed by Pant Lauki-4 (4.3). The highest fruit yield was recoeded in Tvpm Local (43.98 $\mathrm{t} \mathrm{ha}^{-1}$ ) with crop duration of 129.4 days. The highest TSS and ascorbic acid content were noted in the BG-3 $\left(2.5^{\circ} \mathrm{B}\right)$ and IC398545 (12.0 mg 100 10 ), respectively. Based on the mean yield performance of the genotypes and selection index score IC 536593, Tvpm Local and Pant lauki-4 were best performing genotypes.
\end{abstract}

Key words: bottle gourd, genotypes, yield, quality, selection index

\section{INTRODUCTION}

Bottle gourd [Langenaria siceraria (Mol.) Standl.] is a vigorous annual climbing vine from Cucurbitaceae family. It is one of the most wellliked cucurbitaceous fruit crops grown worldwide in the tropical climates of India, Sri Lanka, Indonesia, Malaysia, China, and Turkey as well as in most parts of Africa, Europe and South America (Nicola et al., 1999). It is cultivated worldwide for diverse uses such as for food, medicine, containers. Fresh bottle gourd fruit juice is used as medicine to cure various diseases (Ghule et.al, 2007). Its seeds are the potential source of protein, lipid, macro and micro nutrients India being rich source of bottle gourd germplasm with 1,814 accessions (Anjula et al., 2019) and high genetic diversity for fruit traits resulted in a variety of uses in daily human life. It is cultivated in an area of 187 thousand hectares with an annual production of 3011 thousand metric (NHB, 2019). In many parts of India, high yielding verities and hybrids of bottle gourds were cultivated and crop being short duration in nature, fairly resistant to biotic and abiotic stress problems. In this climate changing scenario, the crop can be made fit into many horticultural production systems such as organic farming system, homestead cropping system, multistory cropping system etc. but its adaptability and performance of different genotypes of bottle gourd have not been documented in humid tropical low lands of Kerala. To development of an early maturing and high yielding variety will be helpful to increase the productivity, extent of cultivation and export. Hence, the present investigation was taken up with the objective to screen and characterization 31 bottle gourd genotypes for different yield and quality traits.

\section{MATERIALS AND METHOD}

The present investigation was carried out at the Department of Vegetable Science, College of Agriculture, Vellayani, during 2019 - 2020. The experimental site was located at 8.25 North latitude and 76.59 East longitudes, at an altitude of $13 \mathrm{~m}$ above mean sea level. Predominant soil type of experimental site was red loam belonging to Vellayani series, texturally classified as sandy clay loam. In the experiment, 31 accessions/varieties of long type bottle gourd, collected from public and private sectors, were evaluated for the yield and quality. The evaluation was done in randomized block design 
(RBD) with two replications. Seeds were sown in pro trays filled with growing media composed of coir pith and vermicompost in the ratio 1:1. Seedlings after true-leaf emergence were transplanted into the main field at $3 \times 2 \mathrm{~m}$ spacing. The crop was raised according to the package of practices recommendations for the bottle gourd. Five plants were randomly selected in each genotype from each replication and tagged for recording the biometric observations for the fruit yield and quality parameters and the mean values of the data recorded were analyzed statistically adopting the method suggested by Panse and Sukhatme (1985) . Node to first fruit initiation was recorded by counting number of position from the first true leaf; fruit set per cent was calculated by dividing total number of healthy fruits to total number of female flowers produced into a hundred. Fruit diameter was measured by cutting the fruit in the middle at the vertical axis in centimeter. Days to first harvest was recorded by counting days from sowing to first harvest. Fruit length was measured with the help of meter scale in centimeter $(\mathrm{cm})$ while the fruit diameter was measured across fruit and average value was expressed in centimeter (cm). Rind thickness was measured with the help of digital vernier calipers. Flesh thickness was measured with the help of thread, and it is compared with meter scale by separating the flesh from the skin and expressed in centimeter (cm). Number of fruits per vine was recorded by counting total fruits produced up to last harvest. Fruit weight and yield per hector were recorded in the kilogram $(\mathrm{kg})$ and tones per hector $\left(\mathrm{t} \mathrm{ha}^{-1}\right)$ respectively. Duration of crop was measured in days (d) by counting days taken from sowing to final crop harvest. While the quality parameters like TSS was estimated by hand refractometer scaling 0-32 per cent range and expressed in terms of ${ }^{0}$ Brix. Ascorbic acid content of fruit was estimated by 2, 6-dichlorophenol indophenol dye method (Sadasivam and Manickam, 1992) and

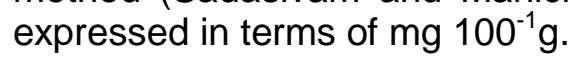

\section{RESULTS AND DISCUSSION}

\section{Fruit yield parameter}

The analyses of variance for thirteen traits of thirty-one genotypes of the bottle gourd are presented in Table 1. A perusal of data (Table 1) indicated that the lower node to first fruit initiation was noticed in BG-3 (13.7) and it was found statistically at par with genotypes viz., IC 284895 (15.0), BG-13 (14.9). IC342077 (19.4) had the higher node to first fruit initiation. The trait fruit set per cent directly contributing to yield of crop i.e., higher the fruit set per cent resulting higher number of fruits per plant and leading to the higher yield per unit area.

Table 1: Analysis of variance for characters in bottle gourd accessions

\begin{tabular}{|c|c|c|c|}
\hline Character & Replication & Genotypes & Error \\
\hline Node to first fruit initiation & 0.15 & $4.13^{\star \star}$ & 0.420 \\
\hline Fruit set (\%) & 61.16 & $78.91^{* *}$ & 4.980 \\
\hline Days to first harvest & 3.96 & $36.48^{\star *}$ & 0.870 \\
\hline Fruit length $(\mathrm{cm})$ & 2.71 & $190.79^{* *}$ & 0.290 \\
\hline Fruit diameter $(\mathrm{cm})$ & 0.03 & $5.86^{* *}$ & 0.040 \\
\hline Rind thickness (mm) & 0.01 & $0.52^{\star *}$ & 0.020 \\
\hline Flesh thickness $(\mathrm{cm})$ & 0.08 & $6.15^{\star *}$ & 0.070 \\
\hline Fruit weight $(\mathrm{kg})$ & 0.027 & $0.255^{\star *}$ & 0.021 \\
\hline Number of fruits per vine & 0.41 & $0.97^{* *}$ & 0.050 \\
\hline Yield ha ${ }^{-1}\left(\mathrm{tha}^{-1}\right)$ & 0.7220 & $95.179 * *$ & 0.096 \\
\hline Duration of crop (d) & 39.31 & $97.09^{\star *}$ & 2.000 \\
\hline TSS ('Brix) & 0.08 & $0.09^{\star *}$ & 0.010 \\
\hline Ascorbic acid content of the pulp $\left(\mathrm{mg} 100^{-1} \mathrm{~g}\right.$ ) & 4.02 & $7.14^{\star *}$ & 1.550 \\
\hline
\end{tabular}

$\frac{\text { Ascorbic acid content of the pulp }\left(\mathrm{mg} 100^{-1} \mathrm{~g}\right)}{\text { Data represent mean sum of squares; }{ }^{*} \text { significant at } P \leq 0.05 ;{ }^{* *} \text { significant at } P \leq 0.01}$

Among the genotypes studied BG-3 produced highest fruit set $(43.4 \%)$ followed by Arka Bahar (35.9\%), IC 371745 (35.5\%) and IC 334300 (35.1 \%). IC342077 (13.2\%) where noted for lowest fruit set. Screening for early maturing genotypes from the gene pool plays key role in development of early maturing and high yielding varieties and hybrids in-order to catch higher market price. Among the genotypes studied BG-2 was earliest to first fruit harvest 
(57.8 days) followed by Naveen (62.9 days), BG3 (63.2 days). IC284891 (74.1 days) was late to first fruit harvest. These results are confirmed with study of Harika et al. (2012), Tomar et al. (2015) in bottle gourd. IC 371745 recorded for longer fruit length $(68.8 \mathrm{~cm})$ which was at par with IC $538142(62.2 \mathrm{~cm})$. BG-3 $(22.9 \mathrm{~cm})$ where recoded for minimum fruit length. Rathore et al. (2017) reported variations in fruit diameter might be due to fruit length and number of fruits per vine. Harika et al. (2012) reported that differences in flesh thickness could be attributed to the inherent traits of cultivars and flesh thickness increases with an increase in size of the fruit. Among the genotypes studied
IC417704 had recorded for highest fruit diameter and flesh thickness $(15.97 \mathrm{~cm}$ and $12.56 \mathrm{~cm}$ ) which was at par with IC146312 $(13.38 \mathrm{~cm}$ and $10.95 \mathrm{~cm})$. While the genotypes BG-1 $(7.35 \mathrm{~cm})$ and Naveen $(4.19 \mathrm{~cm})$ was noted for least fruit diameter and flesh thickness respectively. Highest rind thickness was observed in IC $538142(3.79 \mathrm{~mm})$ and lowest in IC 331101 $(1.69 \mathrm{~mm})$ these variations in rind thickness among genotypes indicate the possibility of selection among genotypes for desired rind thickness. The results are similar to those obtained by Kandasamy et al. (2019), Pandiyan et al. (2019) and Navdeep et al. (2020).

Table 2: Mean performance of bottle gourd genotypes for fruit yield and quality parameters

\begin{tabular}{|c|c|c|c|c|c|c|c|c|c|c|c|c|c|}
\hline Treatments & NFFI & \begin{tabular}{|l|} 
FS \\
$(\%)$
\end{tabular} & DGHD & $\left|\begin{array}{c}\mathrm{FL} \\
(\mathrm{cm})\end{array}\right|$ & $\begin{array}{l}\text { FD } \\
(\mathrm{cm})\end{array}$ & $\begin{array}{c}\mathrm{RT} \\
(\mathrm{mm})\end{array}$ & \begin{tabular}{|c|}
$\mathrm{FT}$ \\
$(\mathrm{cm})$
\end{tabular} & $\begin{array}{l}\text { FW } \\
(\mathrm{kg})\end{array}$ & NFPV & $\mid \begin{array}{c}\text { YPHa } \\
\left(\mathrm{t} \mathrm{ha}^{-1}\right)\end{array}$ & $\begin{array}{l}\text { DC } \\
\text { (d) }\end{array}$ & $\begin{array}{l}\text { T.S.S. } \\
\left({ }^{0} \text { Brix }\right)\end{array}$ & 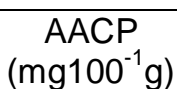 \\
\hline Arka Bahar & 18.9 & 35.9 & 67.2 & 47.8 & 9.83 & 3.46 & 6.38 & 1.59 & 4.2 & 23.72 & 124.2 & 2.15 & 9.2 \\
\hline Pusa Naveen & 16.7 & 25.4 & 71.9 & 34.5 & 9.96 & 2.77 & 7.19 & 2.17 & 3.5 & 23.93 & 129.3 & 1.95 & 10.5 \\
\hline Pant lauki-1 & 16.9 & 29.2 & 69.2 & 50.3 & 11.35 & 3.19 & 8.16 & 2.24 & 4.0 & 31.51 & 126.4 & 2.10 & 7.9 \\
\hline Pant lauki-4 & 16.8 & 23.5 & 68.1 & 55.0 & 10.70 & 2.33 & 8.37 & 2.22 & 4.3 & 32.65 & 125.6 & 1.75 & 7.9 \\
\hline Samrat & 16.0 & 26.6 & 66.0 & 45.4 & 10.86 & 3.09 & 7.77 & 1.84 & 3.9 & 25.98 & 121.5 & 2.15 & 5.3 \\
\hline BG-12 & 17.2 & 28.3 & 64.6 & 44.3 & 8.57 & 3.20 & 5.37 & 2.58 & 3.9 & 25.89 & 117.6 & 2.00 & 7.9 \\
\hline KAR -1 & 18.1 & 27.1 & 70.5 & 42.8 & 11.04 & 2.39 & 8.65 & 1.56 & 3.5 & 20.11 & 128.5 & 1.95 & 6.6 \\
\hline BG-8 & 17.8 & 28.6 & 63.7 & 60.0 & 9.73 & 3.59 & 6.14 & 2.13 & 4.2 & 28.87 & 119.2 & 1.85 & 9.2 \\
\hline$B G-11$ & 15.1 & 24.8 & 63.0 & 48.8 & 10.26 & 2.49 & 7.77 & 1.78 & 3.3 & 21.56 & 130.0 & 1.95 & 6.6 \\
\hline IC146312 & 18.0 & 25.7 & 71.3 & 47.1 & 13.38 & 2.43 & 10.95 & 2.11 & 3.4 & 26.49 & 129.3 & 1.8 & 6.6 \\
\hline Tvpm Local & 14.9 & 30.3 & 72.9 & 52.1 & 8.58 & 2.83 & 5.75 & 2.30 & 6.0 & 43.98 & 129.4 & 2.25 & 7.9 \\
\hline IC 334300 & 17.5 & 35.1 & 68.3 & 50.7 & 10.61 & 3.57 & 7.04 & 1.86 & 3.6 & 21.50 & 125.8 & 1.85 & 9.2 \\
\hline IC284891 & 16.2 & 24.4 & 74.1 & 41.0 & 10.18 & 3.32 & 6.86 & 1.75 & 3.3 & 21.41 & 133.6 & 2.15 & 7.9 \\
\hline IC28 & 15.0 & 30.2 & 66.9 & 40.0 & 10.02 & 2.30 & 7.72 & 2.00 & 3.6 & 25.58 & 124.4 & 1.95 & 9.2 \\
\hline IC311135 & 14.8 & 28.2 & 65.2 & 51.4 & 10.14 & 2.61 & 7.53 & 1.77 & 3.1 & 18.18 & 119.7 & 2.20 & 7.9 \\
\hline IC339196 & 16.7 & 28.2 & 68.2 & 47.4 & 10.35 & 2.90 & 7.44 & 1.48 & 3.9 & 21.50 & 125.6 & 2.00 & 11.8 \\
\hline IC 3 & 15.1 & 22.0 & 63.9 & 51.9 & 9.93 & 1.70 & 8.23 & 1.88 & 2.9 & 18.57 & 121.9 & 1.85 & 9.4 \\
\hline IC 37174 & 18.1 & 35.5 & 66.2 & 68.8 & 9.55 & 2.52 & 7.03 & 2.08 & 3.3 & 21.27 & 124.2 & 1.85 & 10.5 \\
\hline$B G-13$ & 14.9 & 34.8 & 59.6 & 58.9 & 7.92 & 3.54 & 4.38 & 1.89 & 4.2 & 30.10 & 120.1 & 1.80 & 5.3 \\
\hline IC 5 & 16.3 & 21.5 & 72.7 & 42.9 & 11.55 & 3.77 & 7.78 & 2.41 & 3.4 & 27.22 & 131.7 & 2.05 & 10.5 \\
\hline IC 5 & 13.8 & 27.4 & 65.8 & 62.2 & 10.69 & 3.79 & 6.90 & 1.86 & 3.2 & 19.60 & 123.9 & 1.75 & 6.6 \\
\hline IC342077 & 19.4 & 13.2 & 65.0 & 57.8 & 12.75 & 2.78 & 9.97 & 1.95 & 2.9 & 18.09 & 122.9 & 2.00 & 7.9 \\
\hline IC417704 & 17.2 & 22.0 & 71.3 & 33.0 & 15.97 & 3.42 & 12.56 & 1.97 & 3.4 & 20.68 & 137.2 & 2.25 & 9.2 \\
\hline IC398545 & 15.5 & 25.7 & 69.6 & 52.3 & 9.83 & 2.71 & 7.12 & 1.94 & 3.3 & 21.84 & 127.6 & 1.95 & 12.0 \\
\hline$K S_{-1}$ & 15.0 & 20.8 & 66.7 & 40.8 & 9.35 & 2.85 & 6.50 & 1.81 & 3.0 & 19.39 & 124.7 & 2.15 & 7.9 \\
\hline IC343153 & 15.8 & 21.4 & 69.0 & 50.9 & 10.82 & 3.51 & 7.31 & 2.10 & 3.1 & 22.12 & 128.0 & 1.90 & 9.2 \\
\hline BG-1 & 17.8 & 17.9 & 59.3 & 56.6 & 7.35 & 2.81 & 4.54 & 1.98 & 2.7 & 18.62 & 116.8 & 1.60 & 5.3 \\
\hline BG-2 & 17.1 & 14.7 & 57.8 & 39.9 & 9.42 & 2.57 & 6.85 & 1.73 & 2.5 & 16.54 & 115.8 & 1.85 & 5.3 \\
\hline BG-3 & 13.7 & 43.4 & 63.2 & 22.9 & 8.87 & 3.00 & 5.87 & 0.50 & 2.3 & 3.84 & 100.0 & 2.50 & 5.3 \\
\hline Naveen & 16.0 & 25.7 & 62.9 & 52.0 & 7.35 & 3.16 & 4.19 & 2.06 & 3.8 & 32.99 & 114.9 & 1.50 & 9.2 \\
\hline BG-6 & 17.3 & 25.5 & 59.1 & 32.1 & 9.84 & 2.37 & 7.47 & 1.79 & 2.7 & 16.95 & 117.1 & 1.70 & 7.9 \\
\hline SE $(m$ & 0.46 & 1.58 & 0.66 & 0.38 & 0.13 & 0.10 & 0.18 & 0.07 & 0.16 & 0.22 & 1.00 & 0.07 & 0.88 \\
\hline $\mathrm{CD}(0.05)$ & 1.33 & 4.56 & 1.91 & 1.1 & 0.39 & 0.30 & 0.53 & 0.39 & 0.46 & 0.61 & 2.89 & 0.20 & 2.54 \\
\hline
\end{tabular}

NFFI: Node to first fruit initiation, FS: Fruit set (\%), DGH: Days to first harvest, FL: Fruit length (cm), FD: Fruit diameter (cm), $R T$ : Rind thickness (mm), FT: Flesh thickness (cm), FW: Fruit weight (kg), NFPV: Number of fruits per vine, YPHa: Yield per hector $\left.\left(t^{-1}\right)^{-1}\right), D C$ : Duration of crop (d), TSS (Brix): Total soluble solids, AACP: Ascorbic acid content of the pulp (mg $\left.100^{-1} \mathrm{~g}\right)$ 
The average fruit weight ranged from 0.50 to $2.41 \mathrm{~kg}$ with a mean of $1.89 \mathrm{~kg}$. The maximum average fruit weight was recorded by IC $536593(2.41 \mathrm{~kg})$ and it was found statistically at par with genotypes viz., Pant Lauki-1 (2.24 $\mathrm{kg})$, Pant Lauki-4 (2.22 kg). Whereas, BG-3 $(0.50 \mathrm{~kg})$ recorded for minimum average fruit weight. Highest number of fruits per vine was observed in Tvpm Local (6) and lowest in BG-3 (2.3) with overall treatment mean of 3.5. The variation in this trait might be due to differences in sex ration, fruit set per cent and genetic composition of genotypes. The mean fruit yield ranged from $3.84 \mathrm{t} \mathrm{ha}^{-1}$ to $43.98 \mathrm{t} \mathrm{ha}^{-1}$. Maximum average yield was recorded in Tvpm Local (43.98 $\mathrm{t} \mathrm{ha}^{-1}$ ) and it was found statistically at par with genotypes viz., Naveen (32.98 t ha $\left.{ }^{-1}\right)$, Pant Lauki-4 (32.64 t ha $\left.{ }^{-1}\right)$ and Pant Lauki-1 (31.50 t $\left.\mathrm{ha}^{-1}\right)$. Minimum mean yield was recorded in BG-3 (3.84 $\left.\mathrm{t} \mathrm{ha}^{-1}\right)$. Higher yield per hector in Tvpm Local might be due to its better performance in fruit set per cent $(30.3 \%)$, number of fruits per vine (6), fruit weight $(2.3 \mathrm{~kg})$, fruit length $(52.1$ $\mathrm{cm}$ ) and fruit diameter (8.58). These results are similar to those reported by Tirumalesh and Mandaland (2018), Kandasamy et al. (2019), Pandiyan et al. (2019), and Navdeep et al. (2020). IC417704 noted for the maximum crop duration (137.2 days) and it was statistically at par with genotypes viz., IC284891 (133.6 days), IC 536593 (131.7 days). Where BG-3 was noted minimum crop duration of 99.9 days. Similar performance was noticed in crop duration in

\section{REFERENCE}

Anjula, P., Panwar, N.S., Singh, R., and Ahlawat, S.P. (2019) Vegetables: Status and priorities for exploration and germplasm collection in India. ICARNBPGR, New Delhi., India 97p.

Ghule, B.V., Ghante, M.H., Yeole, P.G. and Saoji, A.N. (2007) Diuretic activity of Lagenaria siceraria fruit extracts in rats. Indian Journal of Pharmaceutical Sciences 69(6): 817.

Harika, M., Gasti, V.D., Shantappa, T., Mulge, R., Shirol, A.M., Mastiholi, A.B. and Kulkarni, M.S. (2012) Evaluation of bottle gourd genotypes [Lagenaria siceraria (Mol.) Standl.] for various horticultural characters. Karnataka Journal of Agricultural Sciences 25(2):214-244. bottle gourd by Visen et al. (2014) and Kalyanrao et al. (2016) in the bottle gourd.

\section{Quality parameters}

Among the quality traits studied, the total soluble solids (TSS) content of the fruit pulp varied significantly and treatment mean ranged from 1.5 to $2.5^{\circ} \mathrm{B}$ with overall mean value of $1.96^{\circ}$ B. BG-3 $\left(2.5^{\circ} \mathrm{B}\right)$ noted for highest TSS content this might be due to hydrolysis of complex carbohydrates present in fruit pulp Gajera (2017). The lowest TSS content was noted in Naveen $\left(1.5^{\circ} \mathrm{B}\right)$. The results are similar to those obtained by Rambabu et al. (2017), and Navdeep et al. (2020). The average mean for ascorbic acid content of the pulp was ranged from 5.26 to $12.0 \mathrm{mg} 100^{-1} \mathrm{~g}$. This variation might be due to inherent traits of genotypes and enzymatic and non- enzymatic reactions (Gajera 2017). IC398545 (12.0 mg $\left.100^{-1} \mathrm{~g}\right)$ recorded for highest ascorbic acid content and IC 371745 $\left(10.5 \mathrm{mg} 100^{-1} \mathrm{~g}\right)$ was on par with it. BG-13 $\left(5.3 \mathrm{mg} 100^{-1} \mathrm{~g}\right)$ recorded the lowest ascorbic acid content. The results are similar to those obtained by Rambabu et al. (2017) and lqbal et al. (2019).

Based on the mean yield performance of the genotypes and selection index score superior genotypes identified for yield and quality were viz., IC 536593, Tvpm Local and Pant Lauki-4 these genotypes can be recommended for commercial cultivation.

Iqbal, M., Usman, K., Arif, M., Jatoi, S.A., Munir, M. and Khan, I. (2019) Evaluation of Bottle Gourd Genotypes for Yield and Quality Traits. Sarhad Journal of Agriculture 35(1): 27-35.

Kandasamy, R., Arivazhagan, E. and Bharathi, S.S. (2019) Evaluation of growth and yield characters in bottle gourd (Lagenaria siceraria (Mol.) Standl.). Journal of Pharmacognosy and Phytochemistry 8(3): 4653-4655.

Navdeep, S. and Harpal, S. (2020) Evaluation of bottle gourd [Lagenaria siceraria (Molina) Standl.] genotypes for various growth and yield characters. Asian Journal of Horticulture 15(1):4-6. . 
NHB [National Horticulture Board]. (2019) Indian Horticulture Database 2019 [Online]. Available: http://www.nhb.gov.in/areapro/database

Pandit, M.K., Mahato, B. and Sarkar, A. (2009) Genetic variability, heritability and genetic advance for some fruit character and yield in bottle gourd (Lagenaria siceraria (Mol.) Standl.). Acta Horticulturae 809:221-225.

Pandiyan, R., Pugalenthi, L. and Sathyamurthy, V.A. (2019) Evaluation of vegetative growth and yield performance of bottle gourds (Lagenaria siceraria L.). International Journal of Genetics 11(5): 594-596.

Panse, V.G. and Sukhatme, P.V. (1985) Statistical Methods for Agricultural Workers, ICAR, New Delhi: 1-381.

Rambabu, E., Mandal, A.R., Hazra, P., Senapati, B.K. and Thapa, U. (2017) Morphological characterization and genetic variability Studies in bottle gourd [Lagenaria siceraria (Mol.) Standl.]. International
Journal of Current Microbiology and Applied Sciences 6(9): 3585-3592.

Rathore, J.S., Collis, J.P., Singh, G., Rajawat, K.S. and Jat, B.L. (2017) Studies on genetic variability in ridge gourd [Luffa acutangula L. (Roxb.)] genotypes in Allahabad agro-climate condition. International Journal of Current Microbiology and Applied Sciences 6(2): 317-338.

Sadasivam, S. and Manickam, A. (1992) Phenolics. Biochemical methods for agricultural Sciences 187-188p.

Tirumalesh, M. and Mandal, J. (2018) Evaluation of bottle gourd [Lagenaria siceraria (Mol.) Standl.] genotypes during post-rainy season in red and laterite zone of West Bengal. Journal of Crop and Weed 14(3): 185-188.

Tomar, B.S., Singh, B., and Aher, B.M. (2015) Effect of pollination time on fruit set, seed yield and seed quality of bottle gourd cv. Pusa hybrid-3. Journal of Life Sciences 12(1): 90-94. 